Apidologie, 1977, 8 (2), 141-146.

\title{
OPTIMUM PROTEIN LEVELS REQUIRED BY HONEY BEES (HYMENOPTERA, APIDAE) \\ TO INITIATE AND MAINTAIN BROOD REARING ${ }^{(1,2)}$
}

\author{
Elton W. HERBERT, Jr., H. SHIMANUKI and Dewey CARON * \\ Bioenvironmental Bee Laboratory, Plant Protection Institute ARS, USDA \\ Beltsville, Md. 20705 \\ * University of Maryland College Park, Md. 20740
}

\section{SUMMARY}

Newly emerged honey bees, Apis mellifera L., fed diet containing sucrose plus $23 \%$ protein from a yeast-whey product reared more brood than similar bees fed diets containing $30,10,50$, and $5 \%$ protein in that order. When cellulose was added to the same diets bees fed 5 and $10 \%$ protein reared no brood, but optimum amounts of brood continued to be reared by bees fed diets containing 23 and $30 \%$ protein.

Honey bees, Apis mellifera L., like most insects, require carbohydrates, proteins, fats, minerals, vitamins, and water for growth development, maintenance, and reproduction. Suboptimum levels of these nutrients retard colony development; excessive levels cause dietary imbalances in normal biological processes and make the cost of supplemental feeding prohibitive. However, beekeepers often select pollen substitutes for feeding colonies of honey bees, without regard to the formulation of the diet, deterioration during storage, palatability to the bees, cost of the dietary components, and general availability.

For example, Standifer et al. (1960) found that the rate of hypopharyngeal gland development was apparently related to the protein content of the

1. Part of a thesis submitted by the senior author in partial fulfillment of the requirements of the Ph. D. degree in Entomology, University of Maryland, College Park, Md.

2. Mention of a proprietary product in this paper does not constitute an endorsment of this product by the USDA. 
diet; the best development was obtained at the highest levels (the higher level in Standifer's test was $25 \%$ ), but the lowest levels promoted increased longevity. However, they also pointed out that optimum level of one protein might not be the optimum level of another for promoting longevity in adults and optimal growth of larvae. In fact, honey bees seem unable to utilize high protein diets. DE Groot (1953) noted that bees fed excessive concentrations of protein often had decreased longevity, which he attributed to " protein poisoning 》. MAURIzio (1946) attributed this detrimental effect to the accumulation of undigested materials in the gut.

\section{MATERIALS AND METHODS}

The test diets were fed to bees in small hives $(46 \times 19 \times 27 \mathrm{~cm})$ normally used for queen mating, hereafter referred to as ( nucs ). Nucs were placed in double screen flight cages $(1.5 \times 1.5 \times 3.5 \mathrm{~m})$ and divided into 2 units so that each side consisted of 5 drawn shallow combs $(2.4 \times 17 \mathrm{~cm})$ free of any pollen or honey. Each nuc was stocked with $500 \mathrm{~g}$ of newly emerged Italian worker bees and a mated queen. As soon as the nucs were established, $100 \mathrm{~g}$ of the test diet were placed in a plastic petri dish lid $(15 \times 100 \mathrm{~mm})$ and inverted over the comb frames.

The test diets in both 1974 and 1975 were formulated with Wheast ${ }^{\circledR} *$ to contain $5,10,23,30$, or $50 \%$ protein. Wheast (produced by fermentation of cottage cheese whey by yeast) contains $57 \%$ protein and is high in the B-complex vitamins. The $23 \%$ protein level was tested because this was the average Kjeldahl nitrogen value for pollen collected from 7 geographical locations. In 1974, enough sucrose was added to make up the $100 \mathrm{~g}$ of diet, and warm tap water was then added to make a moist patty. In 1975, the sugar content of each diet was $30.33 \mathrm{~g}$, and Alphacel ${ }^{\circledR}$ and enough warm water to make a patty were added. The carbohydrate level was based on the total reducing and nonreducing sugars found in bee bread collected from 7 geographical locations. Alphacel (cellulose) was added to give bulk to the diet and was of no nutritional value to honey bees. The patties were placed in petri dish lids and weighed before they were inverted over the brood combs. Also, in 1975 the unused portion of the diet was removed and weighed weekly, and control patties were placed in empty nucs to determine the weight loss of the diets due to water evaporation. These differences were subtracted from the weekly rates of consumption. When the lst sealed brood appeared, the amount of sealed cells was estimated by using a wire grid with $2.5-\mathrm{cm}^{2}$ divisions. These brood measurements were made weekly for a period of 10 weeks (May-July).

* Available from Knudsen Creamery Co., P.O. Box 2335, Terminal Annex Los Angeles, Ca. 90054. 


\section{RESULTS AND DISGUSSION}

During the 1974 study, all the bees successfully reared brood, but the most brood rearing occurred when the $23 \%$ protein diet was fed followed in descending order by the 30,10,50 and $5 \%$ levels (Table 1). Bees fed the 2 lower levels were slow in initiating egg laying. The optimum level for brood rearing was thetefote between 23 and $30 \%$, and more occurred at $23 \%$ though the difference was not statistically significant $(P=0.05)$. The consumption of the $50 \%$ protein diet was poor, and many of the younger larvae were removed from the cells before pupation. Also, though the brood pattern of the young larvae was compact, the number reaching the pupal stage was much smaller so the pattern of the sealed cells was spotty.

TABL. 1. - Avg brood rearing $\left(\mathrm{cm}^{2}\right)$ and diet consumption a by bees fed Wheast diets b,c,a

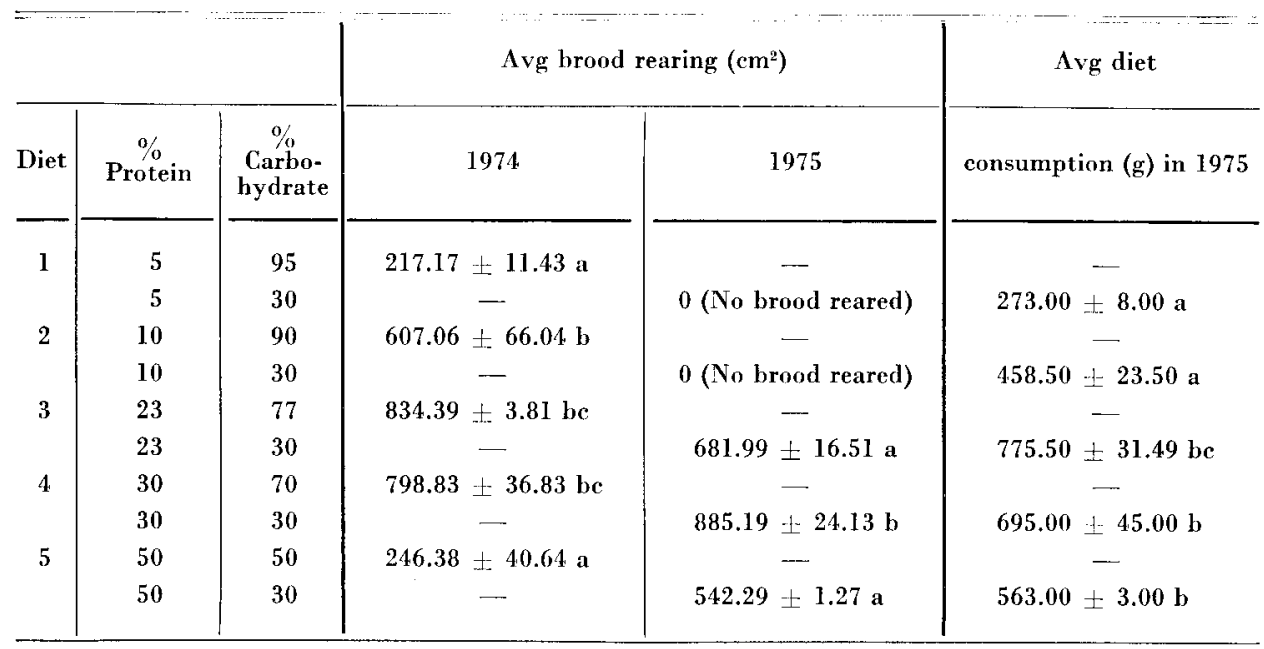

a) Not measured in 1974 .

b) Avg for 2 nucs over a 10 -wk period.

c) Means and standard error from each year are treated individually.

d) Means in the same row followed by the same letter do not differ significantly at the $5 \%$ level of probability by Duncan's multiple range test.

The various amounts of sucrose (91.38-13.80 g) used in the 1974 diets may have added a second variable to the experiment. Then since consumption was not measured, the difference in the sugar levels may have influenced the preferences of the bees.

The 1975 study was conducted to determine whether the protein levels or the carbohydrates stimulated the queen to lay eggs and the colony to rear brood. The bees were offered the 5 protein levels, but the concentration of sucrose in each diet was the same. 
Bees fed the 5 and $10 \%$ protein diets were not able to rear brood in 1975, and consumption was minimum compared with the other test diets. Since the only difference between the 5 and $10 \%$ diets in 1974 and 1975 was the amount of Alphacel, this depressed consumption may have been a response to the Alphacel, which was necessarily present in greater amounts. However, either the higher levels of Alphacel or the smaller amounts of sucrose resulted in fungal growth in the 5 and $10 \%$ protein diets, and they also dried out faster than the other diets.

Consumption and brood rearing with the $23 \%$ protein diet were improved over consumption and brood rearing for the 2 lower diets. However, bees fed the $30 \%$ protein diet reared more sealed brood and consumed less diet than those bees fed the $23 \%$ protein diet though the differences were not significant.

In 1975, consumption of the $50 \%$ diet was poor initially. Consequently the rate of brood rearing increased very slowly. However, eventually, the bees fed the $50 \%$ diet reared more bees to the sealed stage than they did in 1974. The $50 \%$ diet in 1975 did not contain Alphacel because it contained so much Wheast so this difference is difficult to explain.

The greatest amount of brood rearing occurred in colonies fed either $23 \%$ or $30 \%$ protein. The weekly brood production for each diet for 1974 and 1975 is shown in Fig. 1 and 2 respectively.

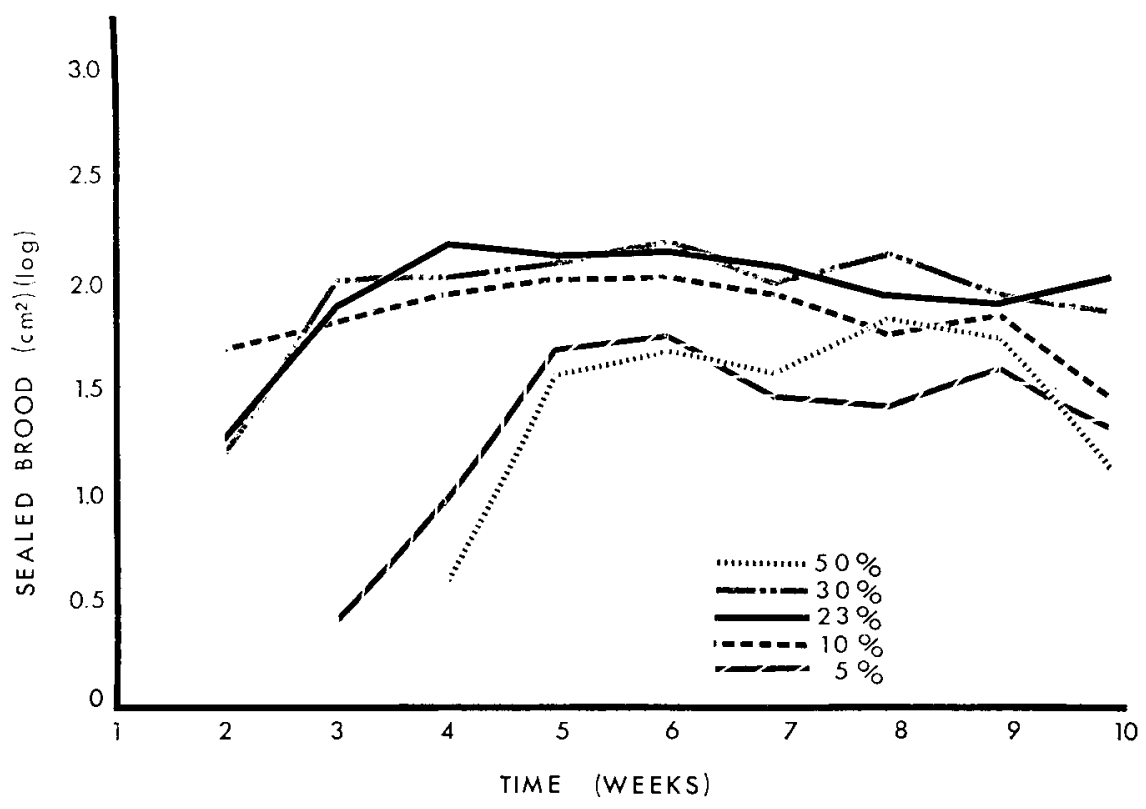

FIG. 1. - Levels of sealed hrood reared in 1974 by bees fed diets containing 5 levels of protein. 


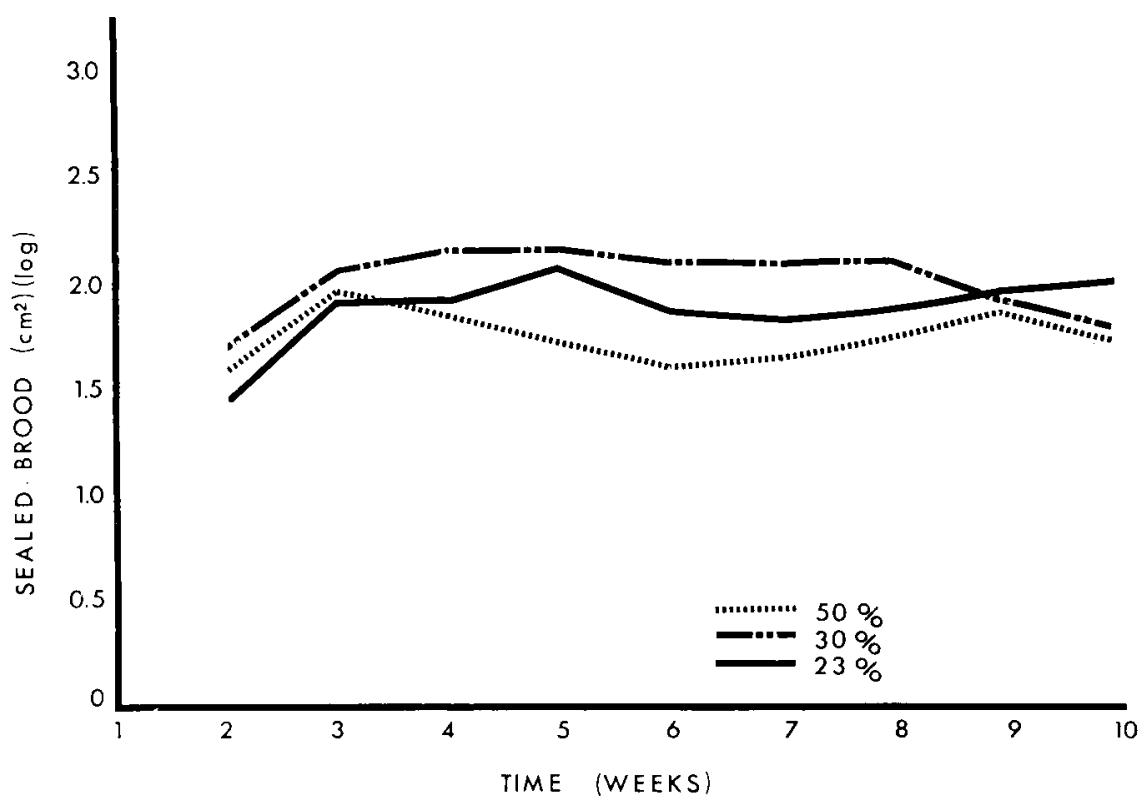

FIG. 2. - Levels of sealed brood reared in 1975 by bees fed diets containing 3 levels of protein.

From the results in 1975 , the bees were not able to compensate for low protein levels in the diet by increasing consumption. Bees fed the 5 and $10 \%$ diets were not able to rear brood successfully because they consumed inadequate amounts of the diets. For example, bees fed the $5 \%$ and $10 \%$ diet consumed averages of 27.30 and $45.85 \mathrm{~g} / \mathrm{wk}$, respectively, but bees fed diets containing 23,30 , and $50 \%$ protein consumed $77.55,69.50$, and 56.30 g respectively. However, from our data it appears that nucs have a minimum protein requirement which must be satisfied for successful brood rearing. Nucs of bees consuming less than $4.61 \mathrm{~g}$ of protein/wk were not able to rear brood. Bees consuming diets containing more than $14.91 \mathrm{~g}$ of protein $(23 \%$ protein diet) were able to successfully rear brood. The analysis of variance $(P=0.05)$ showed that nucs of bees supporting brood rearing consumed significantly more diet than bees not supporting brood rearing. Also the $23 \%$ protein diet was consumed in significantly greater quantities than the 30 and $50 \%$ diets. Regardless of the protein level fed, more diet seemed to be consumed during the lst few weeks of the study than toward the end. 


\title{
RÉSUMÉ
}

\author{
Teneurs optimales en PRoteines nécessaires aUX abeilles \\ (Hymenoptera, Apidae) \\ POUR DÉmarRer ET MaINTENIR L'ÉleVAge DU COUVAIN
}

\begin{abstract}
On a donné à des abeilles, Apis mellifica L., récemment écloses des régimes à diverses teneurs en protéines et on a mesuré la quantité de couvain élevé par les abeilles. Les abeilles qui ont reçu un régime comprenant du sucrose et $23 \%$ de protéines provenant d'un produit mixte levure-petit lait ont élevé plus de couvain que des abeilles semblables ayant reçu des régimes renfermant respectivement $30,10,50$ et $5 \%$ de protéines. Lorsqu'on a ajouté de la cellulose aux mêmes régimes, les abeilles ayant reçu 5 et $10 \%$ de protéines n'ont pas élevé de couvain, mais celles ayant reçu 23 et $30 \%$ de protéines continuèrent à élever les plus grandes quantités de couvain. Les abeilles ont besoin de teneurs optimales en protéines pour l'élevage efficace du couvain et la croissance de la colonie. Des teneurs suboptimales stimulent chez la reine le démarrage de la ponte mais seulement pour de courtes périodes de temps. De trop fortes teneurs en protéines augmentent la mortalité des abeilles et rendent le coût du supplément protéinique prohibitif pour l'apiculteur.
\end{abstract}

\section{ZUSAMMENFASSUNG}

DER FÜR DIE hONIGBIENE (Apis mellifica L.)

ZUR AUSLÖSUNG UND AUFRECHTERHALTUNG

\section{DER BRUTAUfZUCht OPTIMALE PROTEINGEhalt DER NAHRUNG}

Frisch geschlüpfte Bienen (Apis mellifica L.) wurden mit Futter unterschiedlichen Proteingehaltes gefüttert und die von den Bienen aufgezogene Brut ermittelt. Bienen, die mit Saccharose plus $23 \%$ Protein (durch Hefe fermentierte Käsemolke) gefüttert wurden, zogen mehr Brut auf als entsprechende Bienen, deren Futter 30, 10, 50 oder $5 \%$ Protein (in dieser Reihenfolge) enthielt. Wurde dem gleichen Futter Zellulose zugesetzt, zogen die Bienen, die $5 \%$ oder $10 \%$ Protein enthaltendes Futter erhielten, keine Brut auf. Dagegen hatten Bienen optimale Brutmengen, wenn das Futter $23 \%$ oder $30 \%$ Protein enthielt. Zu effektiver Brutaufzucht und Volksentwicklung brauchen die Bienen ein Futter mit optimalem Proteingehalt. Ist der Proteingehalt nicht optimal, wird die Königin zwar zur Eiablage angeregt, jedoch nur für kurze Zeit. Übermässiger Proteingehalt des Futters verbietet sich einmal wegen erhöhter Sterblichkeit der Bienen, zum andern wegen der dem Imker entstehenden zu hohen Kosten des Proteinzusatzes.

\section{REFERENCES}

De Groot A. P., 1953. - Protein and amino acid requirements of the honey bee. Physiol. Comp. Oecol. $3: 1-90$.

Mavrizio A., 1946. - Observation on the life span of bees $\mathrm{kcpt}$ in cages and their food consumption. Beihefte Z. Schweiz. Bienentzg. $2: 1-48$.

Standifer L. N., McCaughey W. F., Todd F. E., and Kemmeren A. R. - 1960. Relative availability of various proteins to the honey bee. Ann. Entomol. Soc. Amer. 53:618-625. 